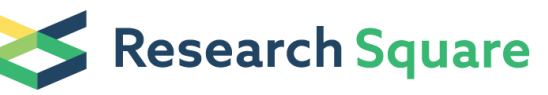

Preprints are preliminary reports that have not undergone peer review. They should not be considered conclusive, used to inform clinical practice, or referenced by the media as validated information.

\section{Fra-2 Overexpression Upregulates Pro-metastatic Cell-adhesion Molecules, Promotes Pulmonary Metastasis and Reduces Survival in a Spontaneous Xenograft Model of Human Breast Cancer}

\author{
Sabrina Arnold \\ University Medical Center Hamburg-Eppendorf: Universitatsklinikum Hamburg-Eppendorf \\ Jan Kortland \\ University Medical Center Hamburg-Eppendorf: Universitatsklinikum Hamburg-Eppendorf \\ Diana V. Maltseva \\ National Faculty of Biology and Biotechnology, National Research University Higher School of \\ Economics
}

Timur R. Samatov

Evotec International $\mathrm{GmbH}$

\section{Susanne Lezius}

University Medical Center Hamburg-Eppendorf: Universitatsklinikum Hamburg-Eppendorf

Alexander G. Tonevitsky

Far Eastern Federal University

Karin Milde-Langosch

University Medical Center Hamburg-Eppendorf: Universitatsklinikum Hamburg-Eppendorf

Daniel Wicklein

University Medical Center Hamburg-Eppendorf: Universitatsklinikum Hamburg-Eppendorf Udo Schumacher

University Medical Center Hamburg-Eppendorf: Universitatsklinikum Hamburg-Eppendorf

Christine Stürken ( $\nabla$ c.stuerken@uke.de)

endorf: Universitatsklinikum Hamburg-Eppendorf https://orcid.org/0000-0003-3997-3304

\section{Research Article}

Keywords: Breast Cancer, Transcription factor, AP-1, Fra-2, Metastasis

Posted Date: June 15th, 2021

DOI: https://doi.org/10.21203/rs.3.rs-592522/v1 
License: (c) (i) This work is licensed under a Creative Commons Attribution 4.0 International License. Read Full License 


\section{Abstract}

\section{Purpose:}

The transcription factor Fra-2 affects the invasive potential of breast cancer cells by dysregulating adhesion molecules in vitro. Previous results suggested that it upregulates the expression of E- and Pselectin ligands. Such selectin ligands are important members of the leukocyte adhesion cascade, which govern the adhesion and transmigration of cancer cells into the stroma of the host organ of metastasis. As so far, no in vivo data are available, this study was designed to elucidate the role of Fra-2 expression in a spontaneous breast cancer metastasis xenograft model.

Methods:

The effect of Fra-2 overexpression in two stable Fra-2 overexpressing clones of the human breast cancer cell line MDA MB231 on survival and metastatic load was studied after subcutaneous injection into scid and $\mathrm{E}$ - and $\mathrm{P}$-selectin deficient scid mice.

Results:

Fra-2 overexpression lead to a significantly shorter overall survival and a higher amount of spontaneous lung metastases not only in scid mice, but also in E- and P-deficient mice, indicating that it regulates not only selectin ligands, but also selectin-independent adhesion processes.

Conclusion:

Thus, Fra-2 expression influences the metastatic potential of breast cancer cells by changing the expression of adhesion molecules, resulting in increased adherence to endothelial cells in a breast cancer xenograft model.

\section{Introduction}

Breast cancer is the most frequent form of cancer in women and the most common cause of female cancer death ${ }^{1}$. Metastasized breast cancer still represents a considerable clinical problem, as it cannot ultimately be cured and thus most patients die because of the metastatic spread to vital organs such as lung, bone marrow and liver ${ }^{2}$. To achieve progress in the treatment of metastasized breast cancer, a better understanding of the process of metastasis formation is therefore necessary. During distant metastasis formation, cancer cells first of all separate from the primary tumour and invade the local stroma, enter the tumour blood vessels and are transported through the circulation to distant sites. Here adhesion to endothelial cells and extravasation into the stroma of the secondary site follows, where some of the emigrated cells eventually grow into clinically detectable metastases ${ }^{3-5}$. Endothelial cells at this site express E- and P-selectins at their luminal surface, which have been previously described as mediators of the first step of leucocyte adhesion and transmigration at sites of inflammation. Comparable with leucocyte adhesion, studies have demonstrated an involvement of selectins in the attachment and 
transmigration of circulating tumour cells $s^{6,7}$. The particular contribution of selectin expression to cancer progression is defined by the temporal and spatial presence of selectins on the luminal endothelial cell surface but also on the presence of selectin ligands on the cancer cell membrane ${ }^{8}$. The classical (canonical) binding partners of selectins are carbohydrate structures, which must be presented on specialized protein scaffolds that enhance ligand clustering, which enables effective selectin binding 9 . Enhanced selectin ligand expression on tumour cells enables the contact with the endothelium and thereby regulates tumour cell progression ${ }^{8}$.

In a foregoing study, we demonstrated that the overexpression of the transcription factor Fra-2 (FOSL2 or Fos-related antigen-2) in MDA MB231 cells resulted in altered in vitro expression of cell adhesion molecules involved in cell-cell or cell-matrix interactions and investigated the adhesive potential of these transfected cells. A strong increase of transiently adherent (rolling) cells compared with the control cells was observed in laminar flow assays with E-selectin coated surfaces indicating that Fra-2 overexpression upregulates expression of cell adhesion molecules or their ligands, respectively, of the leukocyte adhesion cascade $^{10}$. In particular, the observation that increased Fra-2 expression can lead to increased attachment of the cancer cells to E-selectin suggests that Fra-2 also modulates selectin binding sites in breast cancer cells in vivo and thus allows the tumour cells to adhere to the vascular endothelium via $\mathrm{E}$ selectin.

The expression of these cell adhesion molecules and their ligands underlies the regulation by transcription factors including Fra-2. Fra-2 (Fos-related antigen-2) is part of the AP-1 (activating protein-1) transcription factor complex, consisting of the Fos-, Jun-, ATF- and MAF-protein families ${ }^{11-14}$ that bind to regulatory sequences of various target genes, which in turn are induced by growth factors, cytokines, oncoproteins or tumour promoters like TPA (12-0-tetradecanoylphorbol-13-acetate). They form hetero- or homodimers, whose respective combination determines the genes that are regulated by AP- $1^{12}$. These experimental results are reflected in clinical studies which showed that in breast cancer Fra-2 overexpression is associated with a more aggressive tumour phenotype, which indicates that Fra-2 might be involved in breast cancer progression in vivo ${ }^{15}$ and furthermore several investigations indicated that Fra-2 might play a pivotal role in the progression of diverse human tumour types in vivo ${ }^{16}$. Fra-2

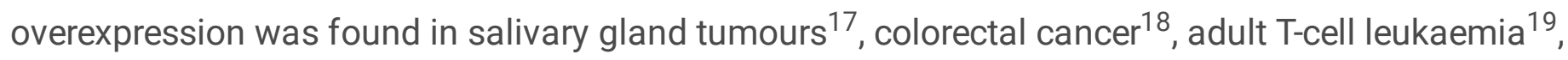
cutaneous T-cell lymphomas ${ }^{20}$ and tongue cancer ${ }^{21}$. Recently it was shown that Fra-2 facilitates TGF-ß1induced migration in non-small cell lung cancer (NSCLC) cells by interaction with the transcription factor $\mathrm{Smad3}^{22}$. Due to these multiple interactions, $\mathrm{Fra}-2$ is an ideal candidate, which can possibly exert a regulatory effect on the expression of many different cell adhesion molecules and their ligands, respectively. We therefore wanted to investigate which of these regulatory effects of Fra-2 operate in an in vivo model of breast cancer metastasis and focused on E- and P- selectin binding sites as the first receptors of the leukocyte adhesion cascade. By studying the effect of Fra-2 overexpression in MDA MB231 breast cancer cells in scid mice and E- and P-selectin deficient mice, we investigated the role of this transcription factor in tumor cell adhesion and metastasis in vivo. By comparison of tumor 
xenografts in both mouse models, we further analysed the role of selectins from both the ligand and the receptor sides during this process.

\section{Materials And Methods}

\section{Cell lines}

All cells derived from the human breast cancer cell line MDA MB231 were cultivated as described before ${ }^{15}$ and stable clones with increased Fra-2 expression had been generated by transfections with the plasmid Fra-2-pIRES containing the full Fra-2 cDNA cloned in the bicistronic vector pIRES ${ }^{15}$. For the following experiments, the MDA-Fra-2 clones (cl) 1 and 2 and the MDA-pIRES clone as negative control were used. All cell lines were routinely tested for mycoplasma infection using the PCR-based VenorGeM Mycoplasma Detection kit (Minerva Biolaps GmBH, Berlin, Germany) according the manufacturer's instructions. Only cells negative for mycoplasma infection were used for further experiments. Authenticity of human cell lines has been confirmed by STR analysis (DSMZ Braunschweig, Germany).

\section{Subcutaneous xenograft mouse model}

In this study female Balb/c severe combined immunodeficient (scid) mice as well as E-selectin - /- and Pselectin -/-scid mice were used. Scid mice had been crossbred with E- and P-selectin deficient mice (Jackson laboratory, stock no: 002916) and selectin deficiency was verified as described previously ${ }^{23}$. The mice were housed under pathogen-free conditions in IVC cages and provided with sterile food and water ad libitum. For injection into mice cells from MDA-Fra-2 clone 1 and 2 and as negative control MDApIRES cells were adjusted to $5 \times 106 \mathrm{ml}-1$ medium. $200 \mu \mathrm{l}$ of this suspension were injected subcutaneously between the scapulae of each mouse. Cells from every cell line were injected into groups of 20 animals each. When the primary tumours had reached maximum $20 \%$ of the body weight of the animal at the beginning of the experiment or ulcerated, the mice were terminally narcotized, and then sacrificed by cardiocentesis and cervical dislocation. Right lungs were excised en bloc and prepared for histologic analysis; left lungs were subjected to DNA-isolation. Bone marrow was received by flushing the left femora with $1 \mathrm{ml} \mathrm{NaCl} 0.9 \%$. Two hundred $\mu \mathrm{l}$ of blood and the bone marrow suspension were subjected to DNA isolation. Then primary tumours were removed, weighed and processed for histologic analysis, RNA isolation and protein isolation.

\section{Ethical Approval and Informed Consent}

The methodology for carrying out the animal experiments was consistent with the UKCCCR guidelines for the welfare and use of animals in cancer research ${ }^{24}$ and were carried out in compliance with the appropriate Animal Research: Reporting in vivo Experiment (ARRIVE) guidelines ${ }^{25}$. The xenograft experiment was supervised by the animal welfare officer institute and the local licensing authority (Behörde für Soziales, Familie, Gesundheit und Verbraucherschutz, Amt für Lebensmittelsicherheit und 
Veterinärwesen, Hamburg, Germany) approved the experiment under the project No. G09/58. All methods were performed in accordance with the relevant guidelines and regulations by the local authorities.

\section{Histology and morphological analysis of spontaneous lung metastases}

One piece of primary tumour, right lung and bone marrow were fixed in $4 \%$ buffered formalin and processed for wax histology. Five $\mu \mathrm{m}$ sections were cut from primary tumours for immunohistochemistry and hematoxylin and eosin (H.E.) staining. The lungs were fixed en block and subsequently cut into $1 \mathrm{~mm}$ thick slices and embedded in $2 \%$ agar. Afterwards the lung slices were paraffin-embedded and cut into 5 $\mu \mathrm{m}$ thick sections. Ten sections of each paraffin wax block were H.E. stained and metastases were counted at a 200 -fold magnification using Zeiss Axiophot photomicroscope (Zeiss, Jena, Germany). The total number of lung metastases was determined for all mice using quantitative assessment as described before $^{26}$. Additionally, two series of serial sections out of the middle of each paraffin wax block were preserved for further immunohistological analyses.

DNA extraction and real-time PCR for detection of circulating tumour cells, disseminated tumour cells and lung metastases

DNA extraction of $200 \mu \mathrm{l}$ murine blood was performed using the QIAamp DNA Blood Mini Kit (Qiagen, Hilden, Germany) and for DNA isolation of murine bone marrow and lung the QIAamp DNA Mini Kit (Qiagen, Hilden, Germany) was used, according to manufacturer's instructions. A serial dilution with 10fold dilution of extracted DNA from $1 \times 106$ cell culture cells MDA MB231 to one cell was established. Control samples were isolated from mice without injected tumour cells. To quantify human tumour cells by real-time polymerase chain reaction (PCR) established primers specific for human Alu-sequences were used as described before ${ }^{27}$.

Analyses were performed in triplicates and at least in two independent experiments, for each sample.

\section{RNA isolation and CDNA microarray analysis}

Approximately $50 \mathrm{mg}$ of fresh-frozen primary tumour tissue was crushed in liquid nitrogen. The total RNA was isolated using QIAzol Lysis Reagent (Qiagen, Hilden, Germany) and the miRNeasy Mini Kit (Qiagen, Hilden, Germany), according to manufacturer's instruction. RNA yield was determined by UV absorbance using NanoDrop 1000 Spectrophotometer (Peqlab, Erlangen, Germany). The RNA quality was assessed by analysis of ribosomal RNA band integrity on an Agilent 2100 Bioanalyzer and RNA 6000 LabChip kit (Agilent Technologies, Palo Alto, CA, USA). The RIN values of RNA samples used for microarray analysis were higher than 7.7. The microarray experiments were performed according to the manufacturer's instructions (TermoFisher Scientific UserGuide P/N 703174) and as described in ${ }^{28,29}$. Procedures for cDNA synthesis and labeling were carried out according to the GeneChip WT PLUS Reagent Kit (Applied Biosystems) protocol using $500 \mathrm{ng}$ of total RNA as the starting material. Target DNA fragmentation, labeling, hybridization on Affymetrix Gene Chip Human Transcriptome Array 2.0 microarrays, array washing, staining, and scanning were performed as described in ${ }^{30}$. The raw microarray data (CEL-files) 
were processed using the Affymetrix Expression Console (build 1.4.1.46) with RMA-sketch method. All CEL-files are available in the Gene Expression Omnibus database (www.ncbi.nlm.nih.gov/geo/) under accession number GSE148089.

\section{qRT-PCR analysis}

RNA was reverse transcribed to CDNA using $2 \mu \mathrm{g}$ of total RNA as a starting material. Quantitative PCR analysis was carried out using the SYBR Green 5x qPCRmix-HS SYBR reaction mix (Evrogen, Moscow, Russia). Amplification included 10 min denaturation at $94^{\circ} \mathrm{C}, 40$ cycles $20 \mathrm{~s}$ melting at $94^{\circ} \mathrm{C}$ followed by $10 \mathrm{~s}$ annealing at $64^{\circ} \mathrm{C}$ and $15 \mathrm{~s}$ elongation at $72^{\circ} \mathrm{C}$. Primer pairs were designed and characterized as described in ${ }^{31}$.

PCR efficiencies of all primer sets were higher than 1.9 and lower than 2.17 (Table 1), except for CTSS (1.79), LGALS1 (1.86), and SRGN (1.88). All RNA samples were analyzed in triplicate and averaged. Target genes were normalized to the reference genes PTMA, RPS23, EEF1A1, ACTB, and GAPDH and data were processed based on the $\Delta \Delta \mathrm{Ct}$ method. Reference gene selection and validation were performed using the approach described in ${ }^{31}$.

\section{Protein extraction and Western blot analysis}

For total protein extraction about $100 \mathrm{mg}$ fresh-frozen primary tumour tissue was crushed in liquid nitrogen and immediately suspended in ice cold self-made RIPA lysis buffer containing a protease inhibitor cocktail (Calbiochem, Darmstadt, Germany). The suspension was stored at $-20^{\circ} \mathrm{C}$ until usage. Protein content of each sample was determined by BCA protein assay (Pierce BCA Protein Assay kit, Thermo Scientific, Rockford, IL, USA). Western blots were performed as described previously ${ }^{32}$. For validation of differentially expressed genes, the following primary and secondary antibodies are specified below. Visualization by chemiluminescence reagents (SuperSignal West Pico Chemiluminescent Substrate kit, Thermo Scientific, Rockford, IL, USA) with Hyperfilm ECL films (GE-Healthcare, Freiburg, Germany). Band intensities were quantified by densitometry with GS-800 Calibrated Densitometer (BioRad, München, Germany). The intensities of the specific protein bands were calculated as percentage intensity of the control sample and corrected for equal actin loading.

Commercial antibodies used for Western blot analysis:

Primary antibodies

B-Actin (RRID: AB_626632; cl C-4;1:500; Santa Cruz, Heidelberg, Germany)

Fra-2 (RRID: AB_2107084; cl Q-20;1:200; Santa Cruz, Heidelberg, Germany)

HCAM (RRID: AB 627066; CD44; cl F-4; 1:200; Santa Cruz, Heidelberg, Germany)

ICAM-1 (RRID: AB_627123; cl G-5; 1:250; Santa Cruz, Heidelberg, Germany) 
Integrin $\beta 4$ (RRID: AB_626839; G-7; sc-13127; 1:500; Santa Cruz, Heidelberg, Germany)

L1-CAM (cl UJ 127.11; 1:25; obtained from Altevogt Lab, Heidelberg, ${ }^{33}$ )

ALCAM (RRID: AB_868825; ab49496; 1:500; Abcam, Cambridge, United Kingdom)

$\underline{\text { Secondary antibodies }}$

HRP goat anti-mouse IgG (RRID: AB_631736; 1:8000; sc-2055; Santa Cruz, Heidelberg, Germany)

HRP goat anti-rabbit IgG (RRID: AB_631748; 1:8000; sc-2054; Santa Cruz, Heidelberg, Germany)

Immunohistochemistry

Immunohistochemical analyses were performed on paraffin-embedded sections of the primary tumour and right lungs. Sections were deparaffinized with xylene and rehydrated in a series of graded ethanol to distilled water. Primary Antibodies, secondary antibodies and pretreatment are described below. All sections were counterstained with Mayer`s hemalum. Photographs were taken using Zeiss Axiophot 2 photomicroscope (Zeiss, Jena, Germany).

Commercial antibodies and pretreatment used for immunohistochemical analysis: 


\begin{tabular}{|c|c|}
\hline$\underline{\text { Antibodies }}$ & Pretreatment \\
\hline $\begin{array}{l}\text { Fra-2 (RRID: AB_2107084; cl Q-20;1:50) } \\
\text { (Santa Cruz, Heidelberg, Germany) }\end{array}$ & S1699 (DAKO), microwave \\
\hline $\begin{array}{l}\text { CD44 (RRID: AB_307182; cl L178; 1:100) } \\
\text { (BD - Pharmingen, Heidelberg, Germany) }\end{array}$ & S1699 (DAKO), steamer, $121^{\circ} \mathrm{C}$ \\
\hline $\begin{array}{l}\text { ICAM-1 (RRID: AB_627123; cl G-5; 1:500) } \\
\text { (Santa Cruz, Heidelberg, Germany) }\end{array}$ & S1699 (DAKO), microwave \\
\hline $\begin{array}{l}\text { Integrin } \beta 4 \text { (RRID: AB_10866385; cl 439-9B; 1:25) } \\
\text { (Abcam, Cambridge, United Kingdom) }\end{array}$ & S1699 (DAKO), microwave \\
\hline $\begin{array}{l}\text { LGALS1 (RRID: AB_2136615; ab25138; 1:400) } \\
\text { (Abcam, Cambridge, United Kingdom) }\end{array}$ & Citrate buffer, water bath, $99^{\circ} \mathrm{C}$ \\
\hline $\begin{array}{l}\text { Cortactin (CTTN; RRID: AB_2088281; sc11408; 1:50) } \\
\text { (Santa Cruz, Heidelberg, Germany) }\end{array}$ & S1699 (DAKO), microwave \\
\hline $\begin{array}{l}\text { Tspan8 (RRID: AB_2678899; HPA-044337; 1:50) } \\
\text { (Atlas; Merck, Taufkirchen, Germany) }\end{array}$ & $\mathrm{S} 1699$ (DAKO), $125^{\circ} \mathrm{C}$ \\
\hline $\begin{array}{l}\text { L1-CAM (RRID: AB_2133065; UJ127) } \\
\text { (Abcam, Cambridge, United Kingdom) }\end{array}$ & EDTA, microwave \\
\hline \multicolumn{2}{|c|}{$\begin{array}{l}\text { Secondary antibodies } \\
\text { anti-mouse IgG (RRID: AB_631736; sc-2005; 1:8000; Santa Cruz, Heidelberg, Germany) } \\
\text { anti-rabbit IgG (RRID: AB_631746; sc-2004; 1:8000; Santa Cruz, Heidelberg, Germany) }\end{array}$} \\
\hline
\end{tabular}

Statistical analyses

Data were visualized analyzed using Graph Pad Prism 5.0 (GraphPad Software, La Jolla, CA) and SPSS 22.0 software (IBM, Chicago, IL, USA). An ANOVA with post-hoc group comparisons model was used to compare tumour weight between control and Fra-2 $\mathrm{cl} 1$ and 2. Due to the explorative nature no adjustment for multiplicity was applied. For the number of lung metastases and comparison of disseminated tumour cells a Negative Binomial Generalized Linear Model was applied. The potential confounders tumour weight and time of tumour growth were no independent factors and therefore excluded in all final models. Survival of mice was analysed by Kaplan-Meier survival curves and Log-rank tests. All tests were performed at a significance level of $p=0.05$. All $p$ values are two-sided.

\section{Results}


In order to analyse the functional role of Fra-2 in breast cancer cells, we established stable transfectants with overexpression of the transcription factor in the cell line MDA MB231 with the pIRES-Fra-2 vector as previously described ${ }^{10}$. Strongly enhanced Fra-2 expression levels could be confirmed in two single-cell clones (Fra-2 $\mathrm{cl} 1$ and $\mathrm{cl}$ 2) by western blot analysis (Fig $1 \mathrm{a}$ ).

\section{Fra-2 overexpression leads to shortened overall survival and increased number of metastases in a subcutaneous scid xenograft model of human MDA MB231 cells}

To investigate the effects of Fra-2 in vivo, cells of both clones with Fra-2 overexpression as well as control cells were injected subcutaneously into scid mice (Fra-2 cl 1: 22 mice; Fra-2 cl 2: 18 mice; control: 16 mice; total amount of 56 female mice) for a survival experiment. 47 of 56 mice developed primary tumours, particularly $95.5 \%$ of mice inoculated with Fra-2 $\mathrm{cl} 1,83.3 \%$ of mice inoculated with $\mathrm{Fra}-2 \mathrm{cl} 2$ as well as $68.8 \%$ of mice which were injected with control cells. At necropsy excised control primary tumours were significantly smaller than Fra-2 $\mathrm{cl} 1$ tumours whereas the difference to $\mathrm{cl} 2$ tumours did not reach statistical significance (control mean tumour weight $=0.67 \mathrm{~g}$, Fra- $2 \mathrm{cl} 1$ mean tumour weight $=1.63 \mathrm{~g}$, Fra-2 $\mathrm{cl} 2$ mean tumour weight $=0.87 \mathrm{~g}$; control vs Fra-2 cl $1 \mathrm{p}=0.018$; control vs Fra-2 $\mathrm{cl} 2 \mathrm{p}=0.513$ ) (Fig $1 \mathrm{~b}$ ). The time span between injections of the tumour cells until sacrifice will subsequently be referred to as survival time. Survival analysis demonstrated a significantly longer overall survival of the mice injected with control clone compared to mice injected with the Fra-2 clones 1 and 2 (range 70-342 days, median survival control $=162$ days, median survival Fra- $2 \mathrm{cl} 1=91$ days, median survival Fra-2 $\mathrm{cl} 2=140$ days, $p<0.001$ ) (Fig $1 \mathrm{c}$ ). The presence of microscopically detectable lung metastases was confirmed upon histological examination of the right lung. $94.1 \%$ of mice injected with Fra-2 $\mathrm{cl} 1$ developed lung metastases (range from 264 to 93746 lung metastases, mean $=10785$ ). We detected lung metastases in $54.5 \%$ of mice injected with Fra- $2 \mathrm{cl} 2$ cells (range from 140 to 29744 lung metastases, mean $=3295$, whereas significantly fewer metastases were found in the control group injected with control cells (lung metastases were found in $84.6 \%$ of control mice, range from 89 to 1766 , mean $=576$; control vs Fra- $2 \mathrm{cl} 1$ $\mathrm{p}<0.001$, control vs Fra-2 $\mathrm{cl} 2 \mathrm{p}=0.007$ ) (Fig $1 \mathrm{~d}$ ).

To demonstrate that the Fra-2 overexpression still existed in primary tumours grown in scid mice and their metastases we analysed the Fra-2 expression by immunohistochemistry. Elevated Fra-2 protein levels could be detected in primary tumours of Fra-2 scid mice (Fig $1 \mathrm{e}-\mathrm{g}$ ) and could also be observed in corresponding lung metastases (Fig $1 \mathrm{~h}-\mathrm{m}$ ).

\section{Microarray analyses of resected tumours and validation of genes with dysregulated expression in scid mouse tumours}

Since Fra-2 overexpression also resulted in an increased number of metastases and reduced overall survival in scid mice, cDNA arrays with mRNA isolated from xenograft tumour tissue were performed and analysed (three tumours per group). Genes that were at least two-fold increased or decreased compared with the respective control were further considered to be significantly dysregulated (adjusted p-value below 0.05 ). According to these criteria, 368 (control vs Fra-2 $\mathrm{cl} 1$ ) and 33 (control vs Fra-2 cl 2) genes 
were upregulated and 142 (control vs Fra-2 cl 1) and 130 (control vs Fra-2 cl 2) genes downregulated in scid primary tumours.

The focus of our analyses was directed on genes that are commonly associated with altered adhesion behavior of tumour cells and / or carrying selectin binding sites on the cell surface. In the analysed groups no concordant genes were identified in the resected tumours of injected Fra-2 $\mathrm{cl} 1$ and Fra-2 $\mathrm{cl} 2$ cells, but prospective candidates with corresponding characteristics were found among the upregulated genes in both Fra-2 groups. In particular, genes such as L1-CAM, ITGB4, DSC2 (Desmocollin 2), TSPAN8 (Tetraspanin 8) and 6 or GPR116 have been upregulated and MAN1A1 or MMP1 have been downregulated compared to the control (Table 2). Using qRT-PCR we could validate Fra-2 mediated upregulation for AGRF5 (GPR116), TSPAN8, DSC2, TSPAN6 and MGAT4A (Table 3). We chose L1-CAM, ICAM-1 and CD44- based on earlier results ${ }^{10}$ - and ITGB4 and TSPAN8 to exemplarily verify the microarray results on protein level. In a western blot analysis, we were able to confirm a different regulation of L1-CAM and CD44 in both clones compared to the respective control samples using protein lysates obtained from tumours of the resected mice (Fig 2 a) However, we could only detect a higher expression of ICAM-1 in Fra-2 cl 2 (Fig 2 a), but by immunohistochemical staining of sections from primary tumours and metastases of lung tissue we could validate expression differences of ICAM-1 between both Fra-2 clones compared to the control (Fig 3 b). We also found a visibly stronger expression of L1-CAM, CD44 and ITGB4 in the scid mice primary tumours and lung metastases injected with Fra-2 overexpressing cells by immunohistochemical staining (Fig 3 a, c-d). For TSPAN8, however, we could only detect a positive immunoreactivity in the lungs (Fig 3 e).

\section{E-and P-selectin deficiency in mice leads to longer overall survival}

To examine whether $\mathrm{E}$ - and P-selectin and tumour cell interactions took part in malignant progression in vivo, the transfected cells were injected subcutaneously in a total amount of $53 \mathrm{E}$ - and P-selectin double knock-out scid mice (select), 19 of them with Fra-2 cl 1 cells, 18 with Fra-2 cl 2 cells and 16 with control cells. Primary tumour growth was observed in 38 of 53 mice (71.7\%), more precisely in 18 of 19 mice injected with Fra-2 $\mathrm{cl} 1$ cells (94.7\%) and in 13 of 18 mice injected with Fra-2 cl 2 cells (72.2\%), whereas only 7 of $16(43.8 \%)$ of the control injected mice developed primary tumours after a time period of 300 days in the survival experiment. There was no significant difference between the tumour weights of controls and both Fra-2 clones in the select mice (control mean tumour weight $=1.17 \mathrm{~g}$, Fra- $2 \mathrm{cl} 1$ mean tumour weight $=1.43 \mathrm{~g}$, Fra- $2 \mathrm{cl} 2$ mean tumour weight $=0.61 \mathrm{~g}$; control vs Fra- $2 \mathrm{cl} 1 \mathrm{p}=0.656$; control vs Fra-2 $\mathrm{cl} 1 \mathrm{p}=0.165)$ (Fig $2 \mathrm{~b}$ ) although the termination criteria between the different groups were applied in the same way. However, survival analysis demonstrated a significantly longer overall survival of the select mice injected with control cells compared with select mice injected with the Fra-2 cls 1 and 2 cells, similar to the results in scid mice (range 64-321 days, median survival Fra-2 $\mathrm{cl} 1=87$ days, median survival Fra2 $\mathrm{cl} 2=183$ days, $\mathrm{p}<0.001)($ Fig $2 \mathrm{c}$ ).

Spontaneous lung metastases were histologically detected in $50 \%$ of Fra-2 control cells in select mice (range from 560 to 2786 lung metastases, mean $=620$ ). In comparison, lung metastases were found in 
$100 \%$ of select mice injected with Fra-2 cl 1 cells (range from 1591 to 107184 lung metastases, mean = 15074; $p<0.001$ ), whilst in $66.7 \%$ of select mice injected with Fra- $2 \mathrm{cl} 2$ cells microscopically detectable lung metastases were found (range from 414 to 2688 lung metastases, mean $=1115 ; p=0.155)$ (Fig 2 d).

On comparison of the two experiments to estimate the survival function between the scid and select mice a significantly shorter overall survival of scid $(n=56)$ mice versus select $(n=53)$ mice could be observed (median survival scid $=125$ days, median survival select $=154$ days, $p=0.034$ ) (Fig $2 \mathrm{e}$ ). Due to the median survival advantage of almost 29 days, we assumed that the selectin status of the immunodeficient mice did directly influence overall survival.

Remarkably quantitative real-time Alu-PCR of bone marrow did show significantly reduced numbers of disseminated tumour cells in the select mice compared to the scid mice (mean of DTCs scid mice $=$ 0.2430 cells $/ 60 \mathrm{ng}$ template DNA, mean of DTCs select mice $=0.0360$ cells $/ 60 \mathrm{ng}$ template DNA, $p=$ 0.014) (Fig $2 \mathrm{f}$ ). Almost no detectable human cells were found in the select mice except in one injected with Fra- $2 \mathrm{cl} 1$ cells ( 0.31 cells $/ 60 \mathrm{ng}$ template DNA) and one injected with Fra- $2 \mathrm{cl} 2$ cells $(1.56$ cells/ 60 ng template DNA) ( $4.3 \%$ of mice) compared to the scid mice, where in $47.1 \%$ of mice human DNA was detected in the bone marrow. Taken together our data suggest an essential effect of the selectins on cell engraftment in the bone marrow and lungs.

\section{Microarray analyses of resected tumours and validation of genes with dysregulated expression in select mice tumours}

As Fra-2 overexpression with Fra-2 $\mathrm{cl} 1$ cells transplanted into select mice also led to an increased metastatic load and significantly reduced survival in the select mice; again microarray analyses were performed as described before.

According to our criteria, 497 (control vs Fra-2 cl 1) and 299 (control vs Fra-2 cl 2) genes were found to be upregulated and 404 (control vs Fra-2 cl 1) and 281 (control vs Fra-2 cl 2) genes downregulated in select mice tumours, respectively.

Again, we focused on genes that could putatively play a role in the adhesion of tumour cells to endothelial cells as the gene product can interact with selectins. In both groups (Fra-2 $\mathrm{cl} 1$ and $\mathrm{cl} 2$ ) some interesting genes could be identified, e.g. in the Fra-2 cl 1 primary tumours $L G A L S 1, A D R M 1$ and CTTN, which were upregulated and $L U M$ (Lumican), MAN1A1 and SPARC, which were significantly downregulated. For Fra-2 cl 2 primary tumours, genes such as SRGN (Serglycin) and ESAM were upregulated while CD99 and SELPLG (selectin P ligand) were downregulated (Table 4).

In addition, comparing Fra-2 $\mathrm{cl} 1$ and $\mathrm{cl} 2$ primary tumours in the select group, we found matched genes that were equally regulated by Fra-2 in both clones. CTTN was upregulated; meanwhile MMP2, ZEB2 and SELPLG were downregulated in both clones. Using qRT-PCR we could validate Fra-2 mediated upregulation for ADRM1, GALNT11, BABAM1, ESAM, LGALS1 and CTTN (Table 5). By 
immunohistochemical staining we could confirm some of these gene products like MTA2, ESAM and LGALS1 in primary tumour and in metastasized cells in the lung of the two clones (Fig 4 a -c), but CTTN only in primary tumour sections not in metastatic cells of the lung (Fig $4 \mathrm{~d}$ ).

Further evaluating the microarray data of the scid and the select group, we observed that many genes which are crucial for glycosylation show an altered expression: for example, MAN1A1, MAN2A1, GALNT 5 and 7 were downregulated in Fra-2 $\mathrm{cl} 1$ scid primary tumours, whereas MGAT4A was upregulated. ST8SIA4, B4GALT5 and CSGALNACT2 were found to be downregulated in Fra-2 cl 2 scid primary tumours.

LGALS1, B4GALT6, GALNT11 were upregulated and MGAT5, MAN1A1, MANBA, LUM, GALNT1 and 7, HAPLN3 and ST6GALNAC5 were downregulated in Fra-2 cl 1 select primary tumours, while MGAT4A was upregulated.

\section{Discussion}

The aim of the present experimental study was to elucidate the functional consequences of Fra-2 overexpression for the formation of metastases in a spontaneous breast cancer metastasis model. So far only clinical and in vitro data were available, which showed that Fra-2 overexpression is associated with a significantly shorter disease-free survival for breast cancer patients and in Fra-2 overexpressing cell lines Fra-2 dysregulates genes involved in cell-cell and cell-matrix contacts $^{10,15}$.

Our results from the present scid mouse models demonstrate that Fra-2 overexpression in the injected breast cancer cells leads to a significantly shorter overall survival of the mice and in accordance with this observation a considerable and significantly higher number of microscopically detectable metastases was detected in the animals' lungs (Fig 1 e-m). In order to identify the genes involved in this enhanced metastatic capacity, cDNA microarray analysis of resected primary scid mouse xenograft tumours was performed which identified a considerable number of dysregulated genes, which are known to be involved in metastasis formation.

The attachment of the tumour cells to endothelium is the crucial step during metastasis formation, which is characterized by enhanced adhesive properties of the circulating cells by upregulation of cell adhesion molecules and their ligands, respectively. The general steps of the metastatic cascade can be divided into several phases. The extravasation of tumour cells is initialized by rolling and low-affinity binding at the endothelium mediated by the selectin family. Rolling is followed by tight adhesion through integrins or other members of the large family of adhesion molecules. As cell to cell and cell to matrix adhesion molecules had been identified to be rate limiting for metastasis formation, we focused on this class of molecules ${ }^{34-37}$. Supporting our former in vitro study ${ }^{10}$, we found a higher mRNA expression of the immunoglobulin superfamily cell adhesion molecule L1-CAM in isolated Fra-2 $\mathrm{cl} 1$ scid primary tumours, which could be confirmed by Western blot (Fig 2 a) and IHC analysis including primary tumour sections and metastasized cells in the lungs (Fig 3 a). The expression of L1-CAM is induced by ERK-MAP-kinase 
signaling ${ }^{38,39}$ and MAP/ERK has been shown to be an important upstream regulator of AP-1 signaling ${ }^{12}$. Mechanistically, Fra-2, as heterodimer with a Jun partner, binds conserved AP-1 consensus sites at the L1CAM promoter and is able to mediate transcriptional activation of L1-CAM when Fra-2 is phosphorylated by ERK $1 / 2^{40}$. Results from Dippel et. al. indicate that L1-CAM expression on MDA MB231 cells promotes adherence to activated endothelial cells by binding to endothelial L1-CAM ${ }^{41}$. Enhanced expression resulted in L1-CAM mediated cell adhesion, migration and proliferation, thereby contributing to tumour progression and invasiveness. In nearly all malignancies investigated so far, L1-CAM expression was associated with poor prognosis, tumour progression and metastasis to lymph nodes ${ }^{42}$. A key player in this step of the metastatic cascade is ICAM-1, of which we confirmed a higher expression in the isolated Fra-2 $\mathrm{cl} 2$ scid primary tumours by Western blot (Fig 2 a) and IHC analysis (Fig 3 b). ICAM-1 mediates the adhesion of lymphocytes to endothelial cells ${ }^{43}$ via Integrin aL $\beta 2(L F A-1)^{44}$. As tumour cells do not express aL $\beta 2$ integrins, they use leukocytes as linker cells to adhere to the vascular endothelium by means of an ICAM-1/LFA-1 interaction ${ }^{45}$. It has been shown that MDA MB468 breast cancer cells use this mechanism to adhere to lung endothelial cells ${ }^{46}$. Furthermore, ICAM-1 expression correlated with the metastatic capacity of five human breast cancer cell lines, suggesting its key role in invasion and dissemination ${ }^{47}$. As ICAM-1 contain AP-1 binding sites within their promoter regions, ICAM-1 engagement leads to downstream activation of the MAP-and ERK-1 kinase cascade and subsequent AP-1 transcription factor activity ${ }^{48,49}$. Another member of this immunoglobulin superfamily, namely CD44 was also upregulated by Fra-2 as well in the scid mouse xenograft tumours and metastasized cells in the lungs as confirmed by Western blot (Fig 2 a) immunohistochemistry (Fig $3 \mathrm{c}$ ). CD44 is a cell-surface glycoprotein with a postulated role in cancer metastasis ${ }^{50}$ with binding domains for hyaluronan and other glycosaminoglycans, collagen, laminin and fibronectin, all components of the $\mathrm{ECM}^{51}$.

Overexpression of CD44 has been linked to a number of transcription factors including NFkB and AP- $1^{52}$. Most notably, AP-1 has been shown to have a direct effect on CD44 expression by binding the CD44 promoter ${ }^{53,54}$. In colon carcinoma cells 0 -glycosylated CD44 can bind endothelial E-selectin, which in turns contributes to metastasis ${ }^{55}$. Following the steps of the metastatic cascade integrins like ITGB4, which was highly expressed in Fra-2 overexpressing scid tumours, are also 0-glycosylated and are suspected to influence the attachment of tumour cells to the ECM as well as cell -to cell interactions ${ }^{56}$. Moreover, ITGB4 transactivates EGFR/Her2 signaling and promotes lung metastasis in breast cancer cells ${ }^{57,58}$. It stimulates mammary carcinoma hyper proliferation by inducing phosphorylation and, presumably, activation of c-Jun, the preferred dimer partner of Fra- $2^{12,59}$. In agreement with our previous in vitro study ${ }^{10}$, we could substantiate the expression of L1-CAM, ICAM-1 and CD44 in the scid mouse model injected with Fra-2 overexpressing cells. Furthermore, we found metastasized cells expressing L1CAM, ICAM-1, CD44, ITGB4 and TSPAN8 in corresponding lungs of those scid mice (Fig 3 a-e). Mechanistically, the above-named results imply that Fra-2 participates in the metastatic cascade by regulating signaling functions and ligand interactions of these genes. 
This special role of Fra-2 also becomes clear in the second experimental approach. We were able to show that the select mice had a survival advantage to the scid mice and a reduced metastatic load in the lung, but nevertheless tumour growth and metastasis did occur at a later time point. This growth delay can be explained by the lack of E- and P-selectins on the endothelium of the select mice, as the initial contact and adherence of the tumour cells to the endothelium is hampered and thus gives the mice a survival advantage of about 30 days. However, our studies also demonstrate that the transcription factor Fra- 2 is able to control the expression of other adhesion molecules as well (L1-CAM, ICAM-1, CD44, ITGB4 and TSPAN8) and thus allows the tumour cells to adhere to the selectin-deficient endothelium via these adhesion molecules. Again, microarray analyses of resected tumours of the select mice were performed to identify possible genes that would assure adhesion to the endothelium in the absence of selectin binding partners.

Based on the microarray data, $L G A L S 1$, also known as Galectin-1, exhibited the most significant upregulation. Its transcript was clearly upregulated in tumours resected from select mice injected with Fra-2 $\mathrm{cl} 1$ (Table 4) and we were able to detect the expression of LGALS1 by immunohistochemistry both in the tumours and in metastatic cells in the lungs of animals of both Fra-2 overexpressing clones (Fig 4 c). Galectin-1 is a non-covalent homodimeric galectin, which preferentially recognizes Gal $\beta 1,4 \mathrm{GlcNAC}$ (LacNAc) sequences, which can be present on $\mathrm{N}$ - or 0 -linked glycans ${ }^{60}$. Galectin-1 affects the interaction of tumour cells with endothelial cells, which is critical in invasion and metastasis ${ }^{61}$. Galectin-1 has been observed to arbitrate the adhesion of cancer cells to the ECM; Laminin, fibronectin, and other glycoproteins presented in the basement membrane provide the necessary epitopes for Galectin-1-cellECM cross-linking ${ }^{62-64}$. Nam et.al. confirmed the binding of Galectin-1 to the cell surface via its interaction with ITGB1 in MDA MB231 cells ${ }^{65}$. As Galectin-1 expression is at least in part dependent on the constitutive activation of the AP1 transcription complex, it is one more member of cell adhesion molecules regulated by AP- 1 transcription factors ${ }^{66}$. In summary, this study shows that the transcription factor Fra-2 by virtue of its multiple properties, can activate genes involved in cell adhesion at either the receptor or ligand level, thus promoting adhesion to the endothelium and tumour metastasis. This even takes place in the absence of initial molecules, such as selectins, by activation of other downstream genes which launch the adhesion. Even though Fra-2 appears to be an essential component in the metastasis process through the regulation of several adhesion molecules, it is difficult to envisage Fra-2 as a potential therapeutic target because of its multiple interactions in its function as a transcription factor. Deletion of Fra-2 leads to an early lethality in mice: at birth, knockout puppies suffer from a severe growth defect and die within the first week ${ }^{67}$. Our results furthermore show that the transcription factor Fra-2 plays an ambivalent function in the metastasis of breast cancer. In the presence of selectins, Fra-2 promotes the adhesion of tumour cells to the endothelium due to its influence on the expression of selectin ligands as shown in our in vitro-studies ${ }^{10}$. Yet, as shown in select mice, Fra- 2 can also promote metastasis in the absence of selectins, although more slowly, by activation of selectin-independent adhesion processes. This finding highlights the important role of Fra-2 as a regulator of CAMs of adhesion cascade in breast cancer metastasis. 


\section{Declarations}

Acknowledgement

We are grateful for the excellent technical assistance of Tobias Gosau, Jennifer Schroeder-Schwarz and Christine Knies. The research was partially supported by the Basic Research Program at HSE University and funded by the Russian Academic Excellence Project '5-100'.

\section{Declaration}

\section{Funding}

No funding

Competing interest

The authors declare that they have no competing interests.

\section{Data availability}

The datasets generated during and/or during the current study are available from the corresponding author on reasonable request. The raw data were deposited in the Gene Expression Omnibus database (www.ncbi.nlm.nih.gov/geo/) under accession no. GSE148089.

Code availability

No code

\section{Author Contributions}

Conceptualization: K.M.L., U.S. and C.S.; Methodology: S.A., J.K., D.V.M. and C.S; Data Acquisition / Analysis: S.A., J.K., D.V.M., T.R.S., S.L., K.M.L., D.W., A.G.T. and C.S.; Wrote the Manuscript: S.A., D.W., U.S. and C.S.; Figures: S.A., C.S.; Supervision: K.M.L., D.W., C.S. and U.S. All authors reviewed the Manuscript.

\section{References}

1 Eccles, S. A. et al. Critical research gaps and translational priorities for the successful prevention and treatment of breast cancer. Breast Cancer Res 15, R92, doi:10.1186/bcr3493 (2013).

2 Pantel, K. \& Brakenhoff, R. H. Dissecting the metastatic cascade. Nat Rev Cancer 4, 448-456, doi:10.1038/nrc1370 (2004).

3 Carr, I. \& Orr, F. W. Invasion and metastasis. Can Med Assoc J 128, 1164-1167 (1983). 
4 Fidler, I. J. Tumor heterogeneity and the biology of cancer invasion and metastasis. Cancer Res 38, 2651-2660 (1978).

5 Fidler, I. J. The pathogenesis of cancer metastasis: the 'seed and soil' hypothesis revisited. Nat Rev Cancer 3, 453-458, doi:10.1038/nrc1098 (2003).

6 Gout, S., Tremblay, P. L. \& Huot, J. Selectins and selectin ligands in extravasation of cancer cells and organ selectivity of metastasis. Clin Exp Metastasis 25, 335-344, doi:10.1007/s10585-007-9096-4 (2008).

7 Tremblay, P. L., Auger, F. A. \& Huot, J. Regulation of transendothelial migration of colon cancer cells by E-selectin-mediated activation of p38 and ERK MAP kinases. Oncogene 25, 6563-6573, doi:10.1038/sj.onc.1209664 (2006).

8 Borsig, L. Selectins in cancer immunity. Glycobiology 28, 648-655, doi:10.1093/glycob/cwx105 (2018).

9 Varki, A. Selectin ligands: will the real ones please stand up? J Clin Invest 100, S31-35 (1997).

10 Schroder, C. et al. The transcription factor Fra-2 promotes mammary tumour progression by changing the adhesive properties of breast cancer cells. Eur J Cancer 46, 1650-1660, doi:10.1016/j.ejca.2010.02.008 (2010).

11 Angel, P. \& Karin, M. The role of Jun, Fos and the AP-1 complex in cell-proliferation and transformation. Biochim Biophys Acta 1072, 129-157 (1991).

12 Eferl, R. \& Wagner, E. F. AP-1: a double-edged sword in tumorigenesis. Nat Rev Cancer 3, 859-868, doi:10.1038/nrc1209 (2003).

13 Goetz, J., Chatton, B., Mattei, M. G. \& Kedinger, C. Structure and expression of the ATFa gene. J Biol Chem 271, $29589-29598$ (1996).

14 Vogt, P. K. \& Bos, T. J. jun: oncogene and transcription factor. Adv Cancer Res 55, 1-35 (1990).

15 Milde-Langosch, K. et al. Role of Fra-2 in breast cancer: influence on tumor cell invasion and motility. Breast Cancer Res Treat 107, 337-347, doi:10.1007/s10549-007-9559-y (2008).

16 Milde-Langosch, K. The Fos family of transcription factors and their role in tumourigenesis. Eur J Cancer 41, 2449-2461, doi:10.1016/j.ejca.2005.08.008 (2005).

17 Maruya, S. et al. Gene expression screening of salivary gland neoplasms: molecular markers of potential histogenetic and clinical significance. J Mol Diagn 6, 180-190, doi:10.1016/s15251578(10)60508-9 (2004). 
18 Zhang, W., Hart, J., McLeod, H. L. \& Wang, H. L. Differential expression of the AP-1 transcription factor family members in human colorectal epithelial and neuroendocrine neoplasms. Am J Clin Pathol 124, 11-19, doi:10.1309/T1H2Y2CHWY7PD2BN (2005).

19 Nakayama, T. et al. Aberrant expression of Fra-2 promotes CCR4 expression and cell proliferation in adult T-cell leukemia. Oncogene 27, 3221-3232, doi:10.1038/sj.onc.1210984 (2008).

20 Nakayama, T., Higuchi, T., Oiso, N., Kawada, A. \& Yoshie, O. Expression and function of FRA2/JUND in cutaneous T-cell lymphomas. Anticancer Res 32, 1367-1373 (2012).

21 Gupta, S. et al. Selective participation of c-Jun with Fra-2/c-Fos promotes aggressive tumor phenotypes and poor prognosis in tongue cancer. Sci Rep 5, 16811, doi:10.1038/srep16811 (2015).

22 Wang, J. et al. FOSL2 positively regulates TGF-beta1 signalling in non-small cell lung cancer. PLoS One 9, e112150, doi:10.1371/journal.pone.0112150 (2014).

23 Stubke, K., Wicklein, D., Herich, L., Schumacher, U. \& Nehmann, N. Selectin-deficiency reduces the number of spontaneous metastases in a xenograft model of human breast cancer. Cancer Lett 321, 8999, doi:10.1016/j.canlet.2012.02.019 (2012).

24 Workman, P. et al. Guidelines for the welfare and use of animals in cancer research. Br J Cancer 102, 1555-1577, doi:10.1038/sj.bjc.6605642 (2010).

25 Percie du Sert, N. et al. The ARRIVE guidelines 2.0: updated guidelines for reporting animal research. J Physio/ 598, 3793-3801, doi:10.1113/JP280389 (2020).

26 Jojovic, M. \& Schumacher, U. Quantitative assessment of spontaneous lung metastases of human HT29 colon cancer cells transplanted into SCID mice. Cancer Lett 152, 151-156 (2000).

27 Nehmann, N., Wicklein, D., Schumacher, U. \& Muller, R. Comparison of two techniques for the screening of human tumor cells in mouse blood: quantitative real-time polymerase chain reaction (qRTPCR) versus laser scanning cytometry (LSC). Acta Histochem 112, 489-496, doi:10.1016/j.acthis.2009.05.004 (2010).

28 Khaustova, N. A. et al. Selectin-independent adhesion during ovarian cancer metastasis. Biochimie 142, 197-206, doi:10.1016/j.biochi.2017.09.009 (2017).

29 Kudriaeva, A. et al. The Transcriptome of Type I Murine Astrocytes under Interferon-Gamma Exposure and Remyelination Stimulus. Molecules 22, doi:10.3390/molecules22050808 (2017).

30 Sakharov, D. A. et al. Passing the anaerobic threshold is associated with substantial changes in the gene expression profile in white blood cells. Eur J Appl Physiol 112, 963-972, doi:10.1007/s00421011-2048-3 (2012). 
31 Maltseva, D. V. et al. High-throughput identification of reference genes for research and clinical RT-qPCR analysis of breast cancer samples. J Clin Bioinforma 3, 13, doi:10.1186/2043-9113-3-13 (2013).

32 Schroder, C. et al. Expression and prognostic value of L1-CAM in breast cancer. Oncol Rep 22, 1109-1117 (2009).

33 Ebeling, O. et al. L1 adhesion molecule on human lymphocytes and monocytes: expression and involvement in binding to alpha v beta 3 integrin. Eur J Immunol 26, 2508-2516, doi:10.1002/eji.1830261035 (1996).

34 Gebauer, F. et al. Selectin binding is essential for peritoneal carcinomatosis in a xenograft model of human pancreatic adenocarcinoma in pfp-/rag2-- mice. Gut 62, 741-750, doi:10.1136/gutjnl-2011300629 (2013).

35 Kohler, S., Ullrich, S., Richter, U. \& Schumacher, U. E-/P-selectins and colon carcinoma metastasis: first in vivo evidence for their crucial role in a clinically relevant model of spontaneous metastasis formation in the lung. Br J Cancer 102, 602-609, doi:10.1038/sj.bjc.6605492 (2010).

36 Oliveira-Ferrer, L. et al. Prognostic impact of transcription factor Fra-1 in ER-positive breast cancer: contribution to a metastatic phenotype through modulation of tumor cell adhesive properties. $J$ Cancer Res Clin Oncol 141, 1715-1726, doi:10.1007/s00432-015-1925-2 (2015).

37 Oliveira-Ferrer, L. et al. c-FOS suppresses ovarian cancer progression by changing adhesion. $\mathrm{Br} \mathrm{J}$ Cancer 110, 753-763, doi:10.1038/bjc.2013.774 (2014).

38 Schaefer, A. W. et al. Activation of the MAPK signal cascade by the neural cell adhesion molecule L1 requires L1 internalization. J Biol Chem 274, 37965-37973 (1999).

39 Silletti, S. et al. Extracellular signal-regulated kinase (ERK)-dependent gene expression contributes to L1 cell adhesion molecule-dependent motility and invasion. J Biol Chem 279, 28880-28888, doi:10.1074/jbc.M404075200 (2004).

40 Geismann, C. et al. Up-regulation of L1CAM in pancreatic duct cells is transforming growth factor beta1- and slug-dependent: role in malignant transformation of pancreatic cancer. Cancer Res 69, 4517-4526, doi:10.1158/0008-5472.CAN-08-3493 (2009).

41 Dippel, V. et al. Influence of L1-CAM expression of breast cancer cells on adhesion to endothelial cells. J Cancer Res Clin Oncol 139, 107-121, doi:10.1007/s00432-012-1306-z (2013).

42 Altevogt, P., Doberstein, K. \& Fogel, M. L1CAM in human cancer. Int J Cancer 138, 1565-1576, doi:10.1002/ijc.29658 (2016).

43 Lawson, C. \& Wolf, S. ICAM-1 signaling in endothelial cells. Pharmacol Rep 61, 22-32 (2009). 
44 Simon, S. I., Hu, Y., Vestweber, D. \& Smith, C. W. Neutrophil tethering on E-selectin activates beta 2 integrin binding to ICAM-1 through a mitogen-activated protein kinase signal transduction pathway. $J$ Immuno/ 164, 4348-4358, doi:10.4049/jimmunol.164.8.4348 (2000).

45 Strell, C. \& Entschladen, F. Extravasation of leukocytes in comparison to tumor cells. Cell Commun Signa/ 6, 10, doi:10.1186/1478-811X-6-10 (2008).

46 Strell, C., Lang, K., Niggemann, B., Zaenker, K. S. \& Entschladen, F. Surface molecules regulating rolling and adhesion to endothelium of neutrophil granulocytes and MDA-MB-468 breast carcinoma cells and their interaction. Cell Mol Life Sci 64, 3306-3316, doi:10.1007/s00018-007-7402-6 (2007).

47 Rosette, C. et al. Role of ICAM1 in invasion of human breast cancer cells. Carcinogenesis 26, 943-950, doi:10.1093/carcin/bgi070 (2005).

48 Hubbard, A. K. \& Rothlein, R. Intercellular adhesion molecule-1 (ICAM-1) expression and cell signaling cascades. Free Radic Biol Med 28, 1379-1386, doi:10.1016/s0891-5849(00)00223-9 (2000).

49 Lawson, C., Ainsworth, M., Yacoub, M. \& Rose, M. Ligation of ICAM-1 on endothelial cells leads to expression of VCAM-1 via a nuclear factor-kappaB-independent mechanism. J Immuno/ 162, 2990-2996 (1999).

50 Marhaba, R. \& Zoller, M. CD44 in cancer progression: adhesion, migration and growth regulation. J Mol Histo/ 35, 211-231 (2004).

51 Herrera-Gayol, A. \& Jothy, S. Adhesion proteins in the biology of breast cancer: contribution of CD44. Exp Mol Pathol 66, 149-156, doi:10.1006/exmp.1999.2251 (1999).

52 Foster, L. C. et al. Role of activating protein-1 and high mobility group-I(Y) protein in the induction of CD44 gene expression by interleukin-1 beta in vascular smooth muscle cells. FASEB J 14, 368-378, doi:10.1096/fasebj.14.2.368 (2000).

53 Mandal, C. C., Ghosh-Choudhury, N., Yoneda, T., Choudhury, G. G. \& Ghosh-Choudhury, N. Simvastatin prevents skeletal metastasis of breast cancer by an antagonistic interplay between p53 and CD44. J Biol Chem 286, 11314-11327, doi:10.1074/jbc.M110.193714 (2011).

54 Smith, S. M. \& Cai, L. Cell specific CD44 expression in breast cancer requires the interaction of AP-1 and NFkappaB with a novel cis-element. PLoS One 7, e50867, doi:10.1371/journal.pone.0050867 (2012).

55 Hanley, W. D., Burdick, M. M., Konstantopoulos, K. \& Sackstein, R. CD44 on LS174T colon carcinoma cells possesses E-selectin ligand activity. Cancer Res 65, 5812-5817, doi:10.1158/00085472.CAN-04-4557 (2005). 
56 Oliveira-Ferrer, L., Legler, K. \& Milde-Langosch, K. Role of protein glycosylation in cancer metastasis. Semin Cancer Biol 44, 141-152, doi:10.1016/j.semcancer.2017.03.002 (2017).

57 Abdel-Ghany, M., Cheng, H. C., Elble, R. C. \& Pauli, B. U. The breast cancer beta 4 integrin and endothelial human CLCA2 mediate lung metastasis. J Biol Chem 276, 25438-25446, doi:10.1074/jbc.M100478200 (2001).

58 Yoon, S. O., Shin, S. \& Lipscomb, E. A. A novel mechanism for integrin-mediated ras activation in breast carcinoma cells: the alpha6beta4 integrin regulates ErbB2 translation and transactivates epidermal growth factor receptor/ErbB2 signaling. Cancer Res 66, 2732-2739, doi:10.1158/00085472.CAN-05-2941 (2006).

59 Foletta, V. C. Transcription factor AP-1, and the role of Fra-2. Immunol Cell Bio/ 74, 121-133, doi:10.1038/icb.1996.17 (1996).

60 Elola, M. T., Chiesa, M. E., Alberti, A. F., Mordoh, J. \& Fink, N. E. Galectin-1 receptors in different cell types. J Biomed Sci 12, 13-29, doi:10.1007/s11373-004-8169-5 (2005).

61 Kuwabara, I., Sano, H. \& Liu, F. T. Functions of galectins in cell adhesion and chemotaxis. Methods Enzymo/ 363, 532-552, doi:10.1016/S0076-6879(03)01078-4 (2003).

62 Cousin, J. M. \& Cloninger, M. J. The Role of Galectin-1 in Cancer Progression, and Synthetic Multivalent Systems for the Study of Galectin-1. Int J Mol Sci 17, doi:10.3390/ijms17091566 (2016).

63 Jeschke, U. et al. Binding of galectin-1 (gal-1) to the Thomsen-Friedenreich (TF) antigen on trophoblast cells and inhibition of proliferation of trophoblast tumor cells in vitro by gal-1 or an anti-TF antibody. Histochem Cell Biol 126, 437-444, doi:10.1007/s00418-006-0178-1 (2006).

64 van den Brule, F. A. et al. Galectin-1 modulates human melanoma cell adhesion to laminin. Biochem Biophys Res Commun 209, 760-767, doi:10.1006/bbrc.1995.1564 (1995).

65 Nam, K. et al. Binding of galectin-1 to integrin beta1 potentiates drug resistance by promoting survivin expression in breast cancer cells. Oncotarget 8, 35804-35823, doi:10.18632/oncotarget.16208 (2017).

66 Juszczynski, P. et al. The AP1-dependent secretion of galectin-1 by Reed Sternberg cells fosters immune privilege in classical Hodgkin lymphoma. Proc Natl Acad Sci U S A 104, 13134-13139, doi:10.1073/pnas.0706017104 (2007).

67 Eferl, R., Zenz, R., Theussl, H. C. \& Wagner, E. F. Simultaneous generation of fra-2 conditional and fra-2 knock-out mice. Genesis 45, 447-451, doi:10.1002/dvg.20311 (2007).

\section{Tables}


Table 1. Primer sequences of genes used for qRT-PCR

\begin{tabular}{|c|c|c|c|c|}
\hline Gene symbol & Forward primer $\left(5^{\prime} \rightarrow 3^{\prime}\right)$ & Reverse primer $\left(5^{\prime} \rightarrow 3^{\prime}\right)$ & Efficiency & SD (E) \\
\hline TSPAN8 & TGAGCGCCACAGGGGAAAGT & CTCCATTGACCAAACCGCAGCA & 1,99 & 0,06 \\
\hline TSPAN6 & TGTACTCCACAGAGAGATGCAGACA & ACGAGAGAGGCAGTAGGCGAGA & 1,95 & 0,16 \\
\hline $\mathrm{DSC} 2$ & СTTGCATCAGACCAAGGAGGGAG & AGGCTCATCAGGATCAACCGCA & 1,95 & 0,1 \\
\hline GALNT11 & TGTCATAGACCGCACGCCAG & GCTGTCCAGGAACACAAGGACT & 1,9 & 0,16 \\
\hline ADRM1 & TTGCCATCTGGGGAGTCGCT & AAACGCTTCCACATCGCCCT & 2 & 0,14 \\
\hline BABAM1 & TTCGGACACCAAGGGTCAACTGT & ACGACTCCAGCTTTGGCAGTGA & 1,96 & 0,08 \\
\hline ADGRF5 (GPR116) & ССТСАTСССТTССТGCTGCAAAA & GACTTTCCCCGGCTCTCCGA & 1,94 & 0,09 \\
\hline ESAM & GCTGGAAGTGAGCACAGGGC & GGAGCAATGGCATCCTCCTTGA & 2,05 & 0,06 \\
\hline CTSS & CCCTGGATCACCACTGGCATCT & AGCACCACAAGAACCCATGTCTC & 1,79 & 0,12 \\
\hline MGAT4A & AGCGGCAACCAAGAACATCCTG & ССАCCATTCCTTCTGCAACACCA & 2,04 & 0,09 \\
\hline LGALS1 & ATCATGGCTTGTGGTCTGGT & GCACGAAGCTCTTAGCGTCA & 1,86 & 0,11 \\
\hline MTA2 & AGCAGAGTGCTCCATTCGAC & GGCCACCAGATCTTTGACGA & 2,04 & 0,21 \\
\hline B4GALT6 & ACGTATCTCCCGGAAAACTTCA & AATCCTCGCATATAAGGCAGC & 1,99 & 0,15 \\
\hline CTTN & AGGTGTCCTCTGCCTACCAG & AGCCGCATCCTCATAGACG & 1,95 & 0,09 \\
\hline SRGN & TCTGCAAACTGCCTTGAAGAAAA & CCTGGATTCTCGTCTTTGGAAAA & 1,88 & 0,12 \\
\hline \multicolumn{5}{|l|}{ Reference genes } \\
\hline PTMA & ACCAGCTCCGAAATCACCACCA & AGCAGGGGCGTCTCTTCCAT & 2,17 & 0,08 \\
\hline RPS 23 & CCGTAGTCACCGACGAGACCA & TTGGCTGTTTGGCTTCAACTCCT & 2,09 & 0,09 \\
\hline EEF1A1 & CCCTAAAAGCCAAAATGGGAAA & TAGTGGTGGACTTGCCCGAAT & 1,98 & 0,07 \\
\hline ACTB & CTGGAACGGTGAAGGTGACA & AAGGGACTTCCTGTAACAACGCA & 2,03 & 0,08 \\
\hline GAPDH & GAAGGTGAAGGTCGGAGTC & GAAGATGGTGATGGGATTTC & 2,02 & 0,12 \\
\hline
\end{tabular}

Table 2. Selection of genes, which were deregulated by Fra-2 overexpression in scid mice. The entire list of data is deposited in the Gene Expression Omnibus database (see Data availability). 


\begin{tabular}{|c|c|c|c|c|}
\hline $\begin{array}{l}\text { Gene } \\
\text { Symbol }\end{array}$ & Gene title & $\begin{array}{l}\text { control scid Avg } \\
\text { Signal (log2) }\end{array}$ & $\begin{array}{l}\text { Fra-2 cl1 scid Avg } \\
\text { Signal (log2) }\end{array}$ & $\begin{array}{l}\text { Fold } \\
\text { Change }\end{array}$ \\
\hline \multicolumn{5}{|c|}{ control scid vs Fra-2 cl 1 scid tumour } \\
\hline \multicolumn{5}{|l|}{ Increase } \\
\hline GPR116 & $\begin{array}{l}\text { G protein-coupled receptor } \\
116\end{array}$ & 5,75 & 7,9 & 4,44 \\
\hline TSPAN8 & tetraspanin 8 & 5,89 & 7,72 & 3,55 \\
\hline ITGB4 & integrin, beta 4 & 9,67 & 11,1 & 2,7 \\
\hline DSC2 & desmocollin 2 & 7,75 & 9,14 & 2,64 \\
\hline L1-CAM & L1 cell adhesion molecule & 6,11 & 7,35 & 2,36 \\
\hline ITGA10 & $\begin{array}{l}\text { integrin, alpha 10; integrin } \\
\text { alpha-10-like }\end{array}$ & 6,62 & 7,83 & 2,31 \\
\hline \multicolumn{5}{|c|}{ control scid vs Fra-2 cl 1 scid tumour } \\
\hline \multicolumn{5}{|l|}{ Decrease } \\
\hline MAN1A1 & $\begin{array}{l}\text { mannosidase, alpha, class } \\
1 \mathrm{~A}, \text { member } 1\end{array}$ & 10,27 & 6,68 & $-12,02$ \\
\hline SRPX & $\begin{array}{l}\text { sushi-repeat containing } \\
\text { protein, X-linked }\end{array}$ & 11,66 & 9,24 & $-5,37$ \\
\hline TNC & tenascin $\mathrm{C}$ & 9,67 & 7,27 & $-5,27$ \\
\hline CTSL 1 & cathepsin L1 & 10,42 & 8,6 & $-3,55$ \\
\hline CXCR4 & $\begin{array}{l}\text { chemokine (C-X-C motif) } \\
\text { receptor } 4\end{array}$ & 7,53 & 6,07 & $-2,75$ \\
\hline MAN2A1 & $\begin{array}{l}\text { mannosidase, alpha, class } \\
2 \mathrm{~A} \text {, member } 1\end{array}$ & 10,26 & 8,86 & $-2,63$ \\
\hline ITGB8 & integrin, beta 8 & 8,4 & 7,17 & $-2,33$ \\
\hline$A L C A M$ & $\begin{array}{l}\text { activated leukocyte cell } \\
\text { adhesion molecule }\end{array}$ & 12 & 10,83 & $-2,25$ \\
\hline
\end{tabular}




\begin{tabular}{|c|c|c|c|c|}
\hline Gene Symbol & Gene title & $\begin{array}{l}\text { control scid } \\
\text { Avg Signal } \\
\text { (log2) }\end{array}$ & $\begin{array}{l}\text { Fra-2 } \\
\text { cl2 } \\
\text { scid } \\
\text { Avg } \\
\text { Signal } \\
\text { (log2) }\end{array}$ & $\begin{array}{l}\text { Fold } \\
\text { Change }\end{array}$ \\
\hline \multicolumn{5}{|c|}{ control scid vs Fra-2 cl2 scid tumour } \\
\hline \multicolumn{5}{|l|}{ Increase } \\
\hline CTSS & cathepsin S & 7,66 & 9,44 & 3,41 \\
\hline TSPAN6 & tetraspanin 6 & 8,77 & 10,12 & 2,55 \\
\hline MGAT4A & $\begin{array}{l}\text { mannosyl (alpha-1,3-)-glycoprotein beta-1,4- } \\
\text { N-acetylglucosaminyltransferase, isozyme A }\end{array}$ & 6,78 & 8,1 & 2,49 \\
\hline \multicolumn{5}{|c|}{ control scid vs Fra-2 cl2 scid tumour } \\
\hline \multicolumn{5}{|l|}{ Decrease } \\
\hline MMP1 & matrix metallopeptidase 1 & 8,98 & 5,46 & $-11,47$ \\
\hline ST8SIA4 & $\begin{array}{l}\text { ST8 alpha-N-acetyl-neuraminide alpha-2,8- } \\
\text { sialyltransferase } 4\end{array}$ & 8 & 6,34 & $-3,15$ \\
\hline B4GALT5 & $\begin{array}{l}\text { UDP-Gal:betaGIcNAc beta 1,4- } \\
\text { galactosyltransferase, polypeptide } 5\end{array}$ & 14,54 & 13,02 & $-2,87$ \\
\hline PLAUR & plasminogen activator, urokinase receptor & 11,06 & 9,61 & $-2,72$ \\
\hline ITGB8 & integrin, beta 8 & 8,28 & 6,97 & $-2,47$ \\
\hline CSGALNACT2 & $\begin{array}{l}\text { chondroitin sulfate } \mathrm{N} \text { - } \\
\text { acetylgalactosaminyltransferase } 2 \mathrm{~L}\end{array}$ & 11,79 & 10,49 & $-2,46$ \\
\hline
\end{tabular}

Table 3. Validation of microarray results by qRT-PCR of selected genes.

\begin{tabular}{|c|c|c|c|c|c|c|}
\hline \multirow[t]{2}{*}{ Gene symbol } & \multicolumn{2}{|c|}{ Fra-2 cl1 scid vs control } & \multicolumn{2}{|c|}{ Fra-2 cl2 scid vs control } & \multicolumn{2}{|c|}{$\begin{array}{c}\text { Fra-2 (cl1+cl2) scid vs } \\
\text { control }\end{array}$} \\
\hline & FC & p-value & FC & p-value & FC & p-value \\
\hline AGRF5 (GPR116) & 5,2 & $<0.00001$ & 13,0 & 0,009 & 9,1 & 0,014 \\
\hline TSPAN8 & 7,4 & 0,00014 & 2,8 & 0,009 & 5,1 & 0,002 \\
\hline DSC2 & 3,1 & $<0.00001$ & 1,8 & 0,16 & 2,5 & 0,015 \\
\hline CTSS & 1,2 & 0,18 & 2,1 & 0,007 & 1,7 & 0,033 \\
\hline TSPAN6 & 1,6 & 0,0008 & 3,5 & 0,000016 & 2,5 & 0,0014 \\
\hline MGAT4A & 2,0 & 0,00001 & 8,3 & 0,003 & 5,2 & 0,019 \\
\hline
\end{tabular}

*the non-significant results ( $p$-value $>0,05$ ) are shown in italics. 
Table 4. Selection of genes, which were deregulated by Fra-2 overexpression in select mice. The entire list of data is deposited in the Gene Expression Omnibus database (see Data availability). 


$\begin{array}{lllll}\text { Gene Symbol } & \text { Gene title } & \text { control } & \text { Fra-2 cl1 } & \text { Fold } \\ & \text { select Avg } & \text { select Avg } & \text { Change } \\ & \text { Signal } & \text { Signal } & \\ & (\log 2) & (\log 2) & \\ & & \end{array}$

control select vs Fra-2 cl 1 select tumour

Increase

\begin{tabular}{|c|c|c|c|c|}
\hline LGALS1 & lectin, galactoside-binding, soluble, 1 & 10,34 & 13,22 & 7,39 \\
\hline MTA2 & metastasis associated 1 family, member 2 & 8,93 & 10,79 & 3,62 \\
\hline B4GALT6 & $\begin{array}{l}\text { UDP-Gal:betaGlcNAc beta } \\
\text { 1,4galactosyltransferase, polypeptide } 6\end{array}$ & 7,71 & 9,17 & 2,76 \\
\hline ADRM1 & adhesion regulating molecule 1 & 8,01 & 9,38 & 2,6 \\
\hline CTTN & cortactin & 9,17 & 10,52 & 2,54 \\
\hline GALNT11 & $\begin{array}{l}\text { UDP-N-acetyl-alpha-D- } \\
\text { galactosamine:polypeptide N- } \\
\text { acetylgalactosaminyltransferase } 11 \\
\text { (GalNAc-T11) }\end{array}$ & 7,32 & 8,44 & 2,17 \\
\hline BABAM1 & BRISC and BRCA 1 A complex member 1 & 9,77 & 10,82 & 2,07 \\
\hline
\end{tabular}

\section{control select vs Fra-2 cl 1 select tumour}

\section{Decrease}

\begin{tabular}{|c|c|c|c|c|}
\hline CTSO & cathepsin 0 & 10,86 & 7,66 & $-9,17$ \\
\hline MGAT5 & $\begin{array}{l}\text { mannosyl (alpha-1,6-)-glycoprotein beta- } \\
\text { 1,6-N-acetyl-glucosaminyltransferase }\end{array}$ & 10,86 & 8,07 & $-6,92$ \\
\hline MAN1A1 & mannosidase, alpha, class $1 \mathrm{~A}$, member 1 & 11,12 & 8,44 & $-6,39$ \\
\hline MMP2 & matrix metallopeptidase 2 & 8,75 & 6,15 & $-6,04$ \\
\hline CTSL 1 & cathepsin L1 & 11,16 & 8,67 & $-5,62$ \\
\hline LUM & lumican & 6,71 & 4,52 & $-4,56$ \\
\hline PDGFC & platelet derived growth factor $\mathrm{C}$ & 11,41 & 9,54 & $-3,66$ \\
\hline MANBA & mannosidase, beta $\mathrm{A}$ & 8,93 & 7,31 & $-3,07$ \\
\hline$\angle D O C 1$ & leucine zipper, downregulated in cancer 1 & 6,58 & 5,18 & $-2,63$ \\
\hline SPARC & $\begin{array}{l}\text { secreted protein, acidic, cysteine-rich } \\
\text { (osteonectin) }\end{array}$ & 8,79 & 7,41 & $-2,59$ \\
\hline GALNT1 & $\begin{array}{l}\text { UDP-N-acetyl-alpha-D- } \\
\text { galactosamine:polypeptide } \mathrm{N}- \\
\text { acetylgalactosaminyltransferase } 1 \\
\text { (GalNAc-T1) }\end{array}$ & 13,99 & 12,69 & $-2,46$ \\
\hline
\end{tabular}




\begin{tabular}{|llllc|} 
ZEB2 & ZEB2 & 7,86 & 6,58 & $-2,43$ \\
\hline GALNT7 & $\begin{array}{l}\text { UDP-N-acetyl-alpha-D- } \\
\text { galactosamine:polypeptide N- } \\
\text { acetylgalactosaminyltransferase } \\
\text { (GalNAc-T7) }\end{array}$ & 11,26 & 10,11 & $-2,22$ \\
HAPLN3 & hyaluronan and proteoglycan link protein 3 & 6,88 & 5,73 & $-2,21$ \\
\hline SELPLG & selectin P ligand & 6,78 & 5,68 & $-2,14$ \\
\hline ST6GALNAC55 & $\begin{array}{l}\text { ST6 (alpha-N-acetyl-neuraminyl-2,3-beta- } \\
\text { galactosyl-1,3)-N-acetylgalactosaminide } \\
\text { alpha-2,6-sialyltransferase 5 }\end{array}$ & 6,16 & 5,15 & $-2,02$ \\
\hline
\end{tabular}




\begin{tabular}{|c|c|c|c|c|}
\hline \multirow[t]{2}{*}{$\begin{array}{l}\text { Gene } \\
\text { Symbol }\end{array}$} & \multirow[t]{2}{*}{ Gene title } & \multirow[t]{2}{*}{$\begin{array}{l}\text { control select Avg } \\
\text { Signal ( }(\log 2)\end{array}$} & $\begin{array}{l}\text { Fra-2 cl2 } \\
\text { scid }\end{array}$ & \multirow[t]{2}{*}{$\begin{array}{l}\text { Fold } \\
\text { Change }\end{array}$} \\
\hline & & & $\begin{array}{l}\text { Avg } \\
\text { Signal } \\
(\log 2)\end{array}$ & \\
\hline
\end{tabular}

control select vs Fra-2 cl 2 select tumour

Increase

\begin{tabular}{lllll} 
SRGN & serglycin & 8,46 & 13,88 & 42,74 \\
CTTN & cortactin & 9,17 & 10,42 & 2,36 \\
\hline ESAM & endothelial cell adhesion molecule & 6,47 & 7,52 & 2,06
\end{tabular}

control select vs Fra-2 cl 2 select tumour

\section{Decrease}

\begin{tabular}{|c|c|c|c|c|}
\hline CDON & $\begin{array}{l}\text { cell adhesion associated, oncogene } \\
\text { regulated }\end{array}$ & 9,79 & 7,02 & $-6,83$ \\
\hline MMP2 & matrix metallopeptidase 2 & 8,75 & 6,01 & $-6,65$ \\
\hline CD99 & CD99 molecule & 11,56 & 8,86 & $-6,53$ \\
\hline MANBA & mannosidase, beta $A$ & 8,93 & 6,55 & $-5,19$ \\
\hline PLAUR & $\begin{array}{l}\text { plasminogen activator, urokinase } \\
\text { receptor }\end{array}$ & 11,97 & 9,7 & $-4,84$ \\
\hline$C T S B$ & cathepsin B & 12,27 & 10,13 & $-4,39$ \\
\hline DSG2 & desmoglein 2 & 14,58 & 12,53 & $-4,14$ \\
\hline$O G T$ & $\begin{array}{l}\text { O-linked N-acetylglucosamine (GlcNAc) } \\
\text { transferase }\end{array}$ & 12,93 & 10,88 & $-4,12$ \\
\hline SMAD4 & SMAD family member 4 & 10,69 & 8,77 & $-3,8$ \\
\hline SMAD2 & SMAD family member $2 \mathrm{~L}$ & 11,16 & 9,53 & $-3,08$ \\
\hline CTSL 1 & cathepsin L1 & 11,16 & 9,67 & $-2,8$ \\
\hline GLB1 & galactosidase, beta 1 & 8,94 & 7,49 & $-2,72$ \\
\hline ST8SIA4 & $\begin{array}{l}\text { ST8 alpha- } \mathrm{N} \text {-acetyl-neuraminide alpha- } \\
\text { 2,8-sialyltransferase } 4\end{array}$ & 7,3 & 5,86 & $-2,71$ \\
\hline GJB2 & gap junction protein, beta 2 & 7,8 & 6,39 & $-2,67$ \\
\hline SELPLG & selectin P ligand & 6,78 & 5,39 & $-2,62$ \\
\hline MAN2B2 & $\begin{array}{l}\text { mannosidase, alpha, class } 2 B \text {, member } \\
2\end{array}$ & 8,85 & 7,56 & $-2,44$ \\
\hline
\end{tabular}




\begin{tabular}{|lllll|} 
ZEB2 & ZEB2 & 7,86 & 6,57 & $-2,44$ \\
\hline SMAGP & small cell adhesion glycoprotein & 9,13 & 8,04 & $-2,13$ \\
\hline JUNB & jun B proto-oncogene & 8,12 & 7,07 & $-2,07$ \\
\hline
\end{tabular}

Table 5. Validation of microarray results by qRT-PCR of selected genes.

\begin{tabular}{|l|r|r|r|r|r|r|}
\hline \multirow{2}{*}{ Gene symbol } & \multicolumn{1}{|c|}{ Fra-2 cl1 select vs control } & \multicolumn{6}{|c|}{ Fra-2 cl2 select vs control } & Fra-2 (cl1+cl2) & select vs control \\
\cline { 2 - 8 } & FC & \multicolumn{1}{|c|}{ p-value } & \multicolumn{1}{c|}{ FC } & p-value & FC & \multicolumn{1}{c|}{ p-value } \\
\hline ADRM1 & 0,91 & 0,24 & 0,78 & 0,11 & 0,85 & 0,15 \\
\hline GALNT11 & 4,23 & $<0.00001$ & 1,38 & 0,049 & 2,81 & 0,028 \\
\hline BABAM1 & 1,48 & 0,000069 & 1,09 & 0,40 & 1,28 & 0,14 \\
\hline ESAM & 8,32 & $<0.00001$ & 3,76 & 0,0041 & 6,04 & 0,0022 \\
\hline LGALS1 & 1,5 & 0,020 & 2,2 & 0,044 & 1,8 & 0,051 \\
\hline MTA2 & 1,9 & 0,14 & 1,1 & 0,25 & 1,5 & 0,16 \\
\hline B4GALT6 & 1,0 & 0,45 & 1,4 & 0,12 & 1,2 & 0,20 \\
\hline CTTN & 4,7 & 0,0024 & 1,8 & 0,025 & 3,3 & 0,031 \\
\hline SRGN & 1,8 & 0,097 & 13,6 & 0,00024 & 7,7 & 0,053 \\
\hline
\end{tabular}

*the non-significant results (p-value $>0,05$ ) are shown in italics.

\section{Figures}




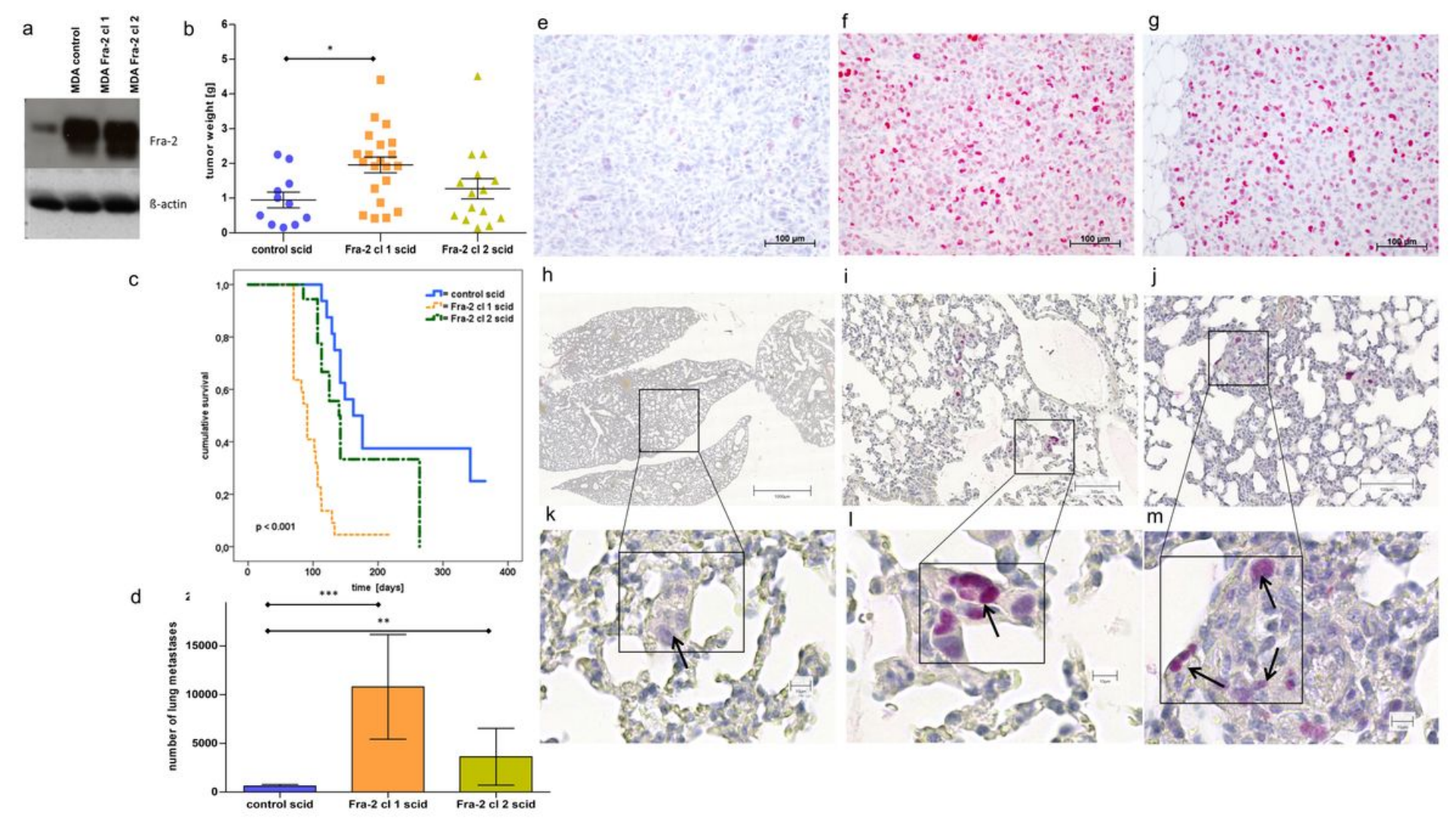

\section{Figure 1}

Effect of Fra-2 overexpression on MDA MB231 cells in vitro and in vivo. (a) Western Blot analysis of human total cell lysates showing Fra-2 overexpression in clones 1 and 2 relative to the MDA MB231 stably transfected cells harboring the empty pIRES-P vector (MDA control). ß-actin was used as loading control. The Blot is cropped for clarity, with full length blot presented in Fig S1. (b) Tumour weight of the resected primary tumours from the scid mice. The tumour weight at the time of death was significantly smaller of the control primary tumours than Fra- $2 \mathrm{cl} 1$ tumours (control mean tumour weight $=0.67 \mathrm{~g}$, Fra$2 \mathrm{cl} 1$ mean tumour weight $=1.63 \mathrm{~g}, \mathrm{p}=0.018$; Fra-2 cl 2 mean tumour weight $=0.87 \mathrm{~g}, \mathrm{p}=0.513)(* \star \star: \mathrm{p}$ $<0.005$; **: $p<0.01 ; *: p<0.05$ ).(c) Kaplan-Meier survival curves of Fra-2 overexpressing human MDA MB231 cells transplanted subcutaneously into scid mice (blue line: scid mice transplanted with the empty vector pIRES = control; deepyellow line: scid mice with transplanted Fra-2 cl 1 cells; lightgreen line: scid mice with transplanted Fra-2 $\mathrm{cl} 2$ cells $(\mathrm{p}<0.001)$. Expression of the transcription factor Fra-2 dramatically decreases survival of the mice after subcutaneous injection of human breast cancer cells overexpressing Fra-2. (d) Number of microscopically detectable lung metastases in scid mice showing significant differences between Fra-2 overexpressing and control cells ( ${ }^{\star \star *}: p<0.005 ; * \star: p<0.01 ; *$ : $<$ 0.05). Bars represent SEM. (e-m) Immunohistochemical staining of primary tumours and lung tissues with metastasized cells from scid mice; minimal Fra-2 expression in a primary tumour (e) and in metastasized cells of lung tissue $(h, k)$ from a scid mouse transplanted with control cells; strong Fra-2 expression in a primary tumour and in metastasized cells of lung tissue from a scid mouse with transplanted Fra- $2 \mathrm{cl} 1$ cells ( $f, j$ and $\mathrm{l}$ ) and Fra- $2 \mathrm{cl} 2$ cells ( $\mathrm{g}, \mathrm{j}$ and $\mathrm{m}$ ). Arrow marks metastatic deposit. Scale bar: 100 and $10 \mu \mathrm{m}$. 


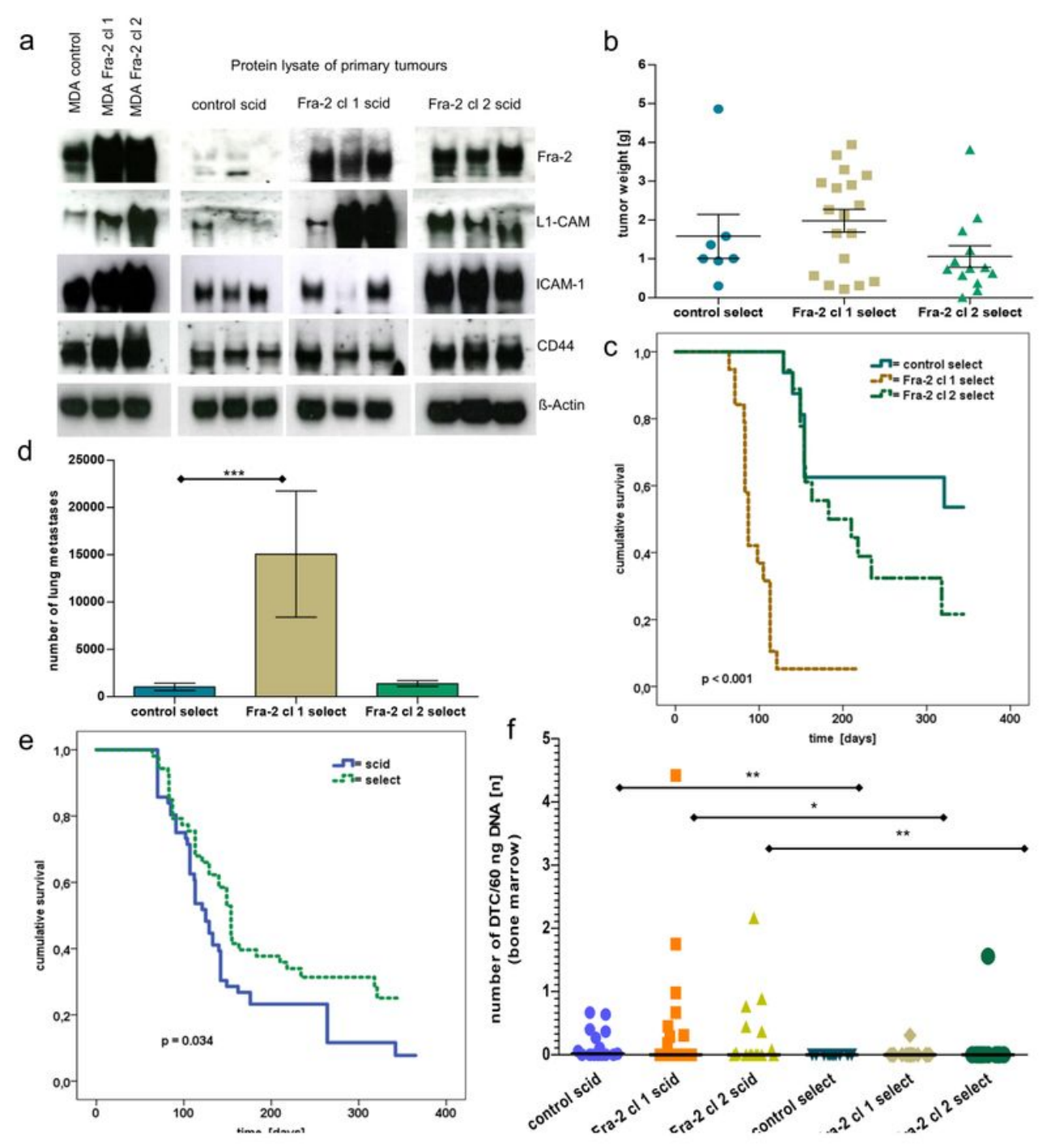

Figure 2

(a) Western blot analysis; cell lysates of the transfected MDA MB231 cells (first 3 rows) and protein lysates of the resected scid mouse primary tumours of control (second 3 rows), Fra-2 $\mathrm{cl} 1$ and 2 cells with staining of L1-CAM, ICAM-1, CD44; (loading control ß-actin). Original non-cropped images of the scanned immunoblot membranes are shown in Figs S2 (a-d), respectively. (b) Tumour weight of the resected primary tumours from the select mice. No significant difference between the tumour weights of control and both Fra-2 clones in the select mice (mean tumour weight: control $=1.17 \mathrm{~g}$, Fra-2 cl $1=1.43 \mathrm{~g}, \mathrm{p}=$ 0.656; Fra-2 cl 2 = 0.61 g, $p=0.165$ ) (***: $p<0.005 ; * *: p<0.01$; $: p<0.05)$. (c) Kaplan-Meier survival curves of Fra-2 overexpressing human MDA MB231 cells transplanted subcutaneously into select mice revealed significantly longer overall survival of the select mice injected with control cells compared with select mice injected with the Fra-2 cls 1 and 2 cells, similar to the results in scid mice (range 64321 days, median survival: Fra-2 $\mathrm{cl} 1=87$ days, and Fra2 $\mathrm{cl} 2=183$ days, $\mathrm{p}<0.001$ ) (oceanblue line: select mice with the empty vector pIRES= control; yellowocher dotted line: select mice with Fra-2 cl 1 cells; mossgreen dashed line: select mice with Fra-2 $\mathrm{cl} 2$ cells $(p<0.001)$. (d) Number of microscopically detectable lung metastases in select mice, the difference between control and Fra-2 $\mathrm{cl} 1$ is clearly significant $(p<0.005)$, 
respectively (***: $p<0.005 ; * *: p<0.01 ; *$ : $<$ 0.05). (e) Remarkably, comparing by Kaplan-Meier analysis, survival curves of scid (blue continuous line) and select mice (green dotted line) showing a significantly better prognosis for the select mice (median survival: $s c i d=125$ days, select $=154$ days, $p=0.034$ ). $(f)$ DTCs in the animals' bone marrow showing a significantly reduced number of disseminated tumour cells in the select mice compared to the scid mice $(p=0.014)(* * *: p<0.005 ; * *: p<0.01 ; *: p<0.05)$. Bars represent SEM.
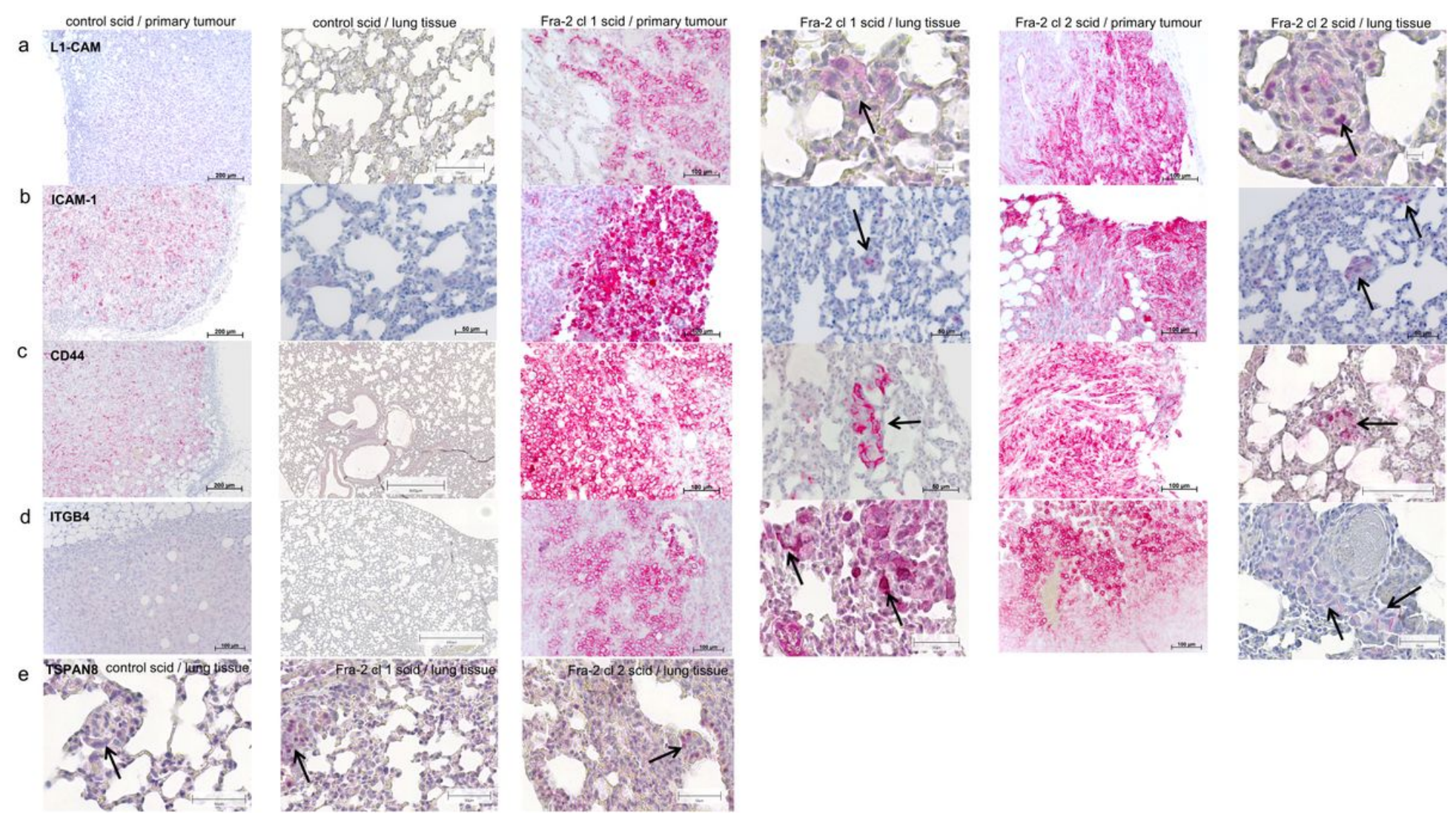

\section{Figure 3}

Immunohistochemistry of primary tumours engrafted in scid mice and their spontaneous metastases in the lung tissue (a-d) IHC staining of representative paraffin embedded primary tumour tissue and lung tissue with metastasized cells grown in scid mice showing a higher immunoreactivity of L1-CAM, ICAM-1, CD44 and ITGB4 in the tumour cells. Scale bar: 200 and $50 \mu \mathrm{m}$. (e) Images of paraffin embedded lung sections of scid mice display an immunoreactivity of TSPAN8 within the metastasized cells. This could indicate that these genes are essential for the tumour cells during the emigration process. Arrows label metastasized cells in the lungs. Scale bar: $100 \mu \mathrm{m}$. 


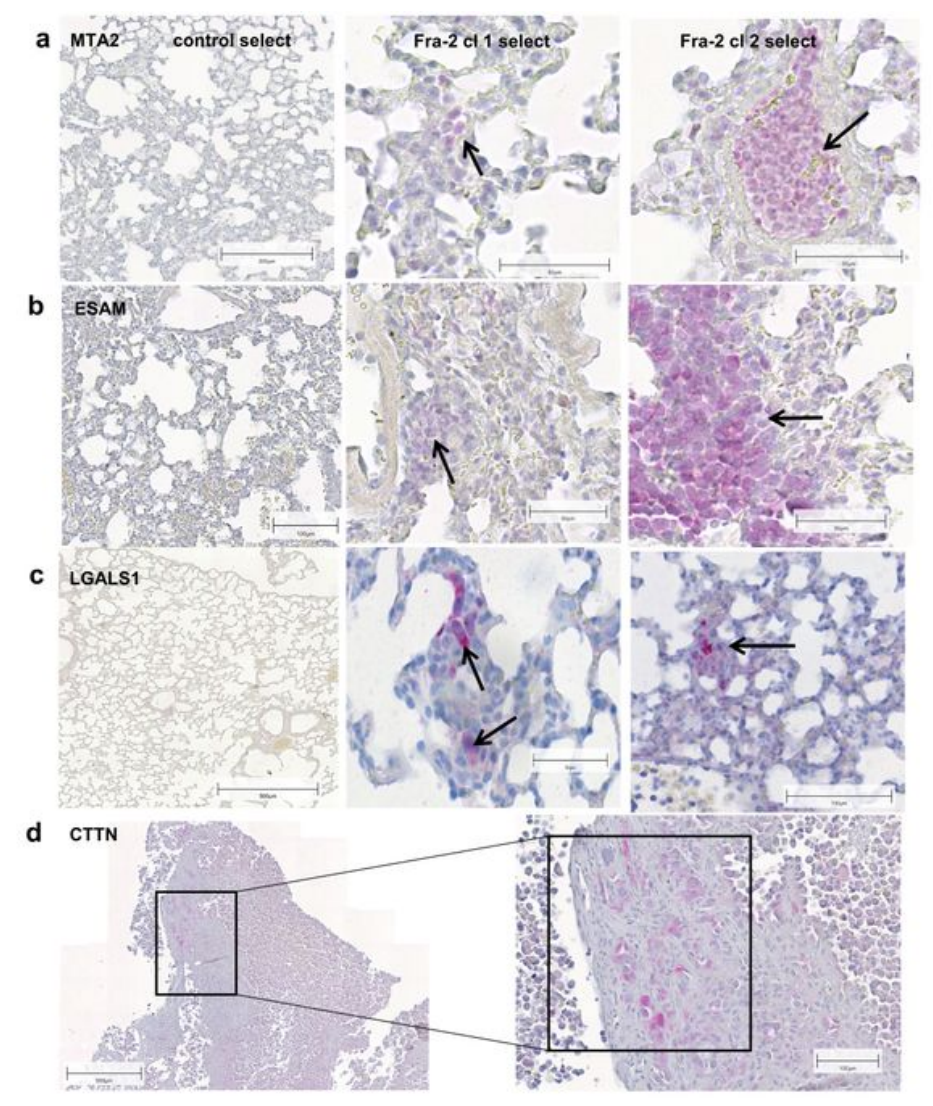

\section{Figure 4}

(a-d) IHC staining of selected up-regulated proteins in representative lung tissue grown in select mice injected with Fra-2 clones showing a higher immunoreactivity of MTA2 (a), ESAM (b) and LGALS1 (Galectin-1) (c) in the metastasized cells. Scale bar: $200-50 \mu \mathrm{m}$. Arrows label metastasized cells in the lungs. (d) IHC staining of primary tumour resected from select mice injected with Fra-2 clone 2 with CTTN positive tumour cells. Scale bar: $500-100 \mu \mathrm{m}$.

\section{Supplementary Files}

This is a list of supplementary files associated with this preprint. Click to download.

- SupplementalMaterialseparatefile.docx 